\title{
Phytophthora ramorum Occurrence in Ornamentals in Serbia
}

Aleksandra Bulajić and Ivana Djekić, Institute of Plant Protection, Department of Phytopathology, University of Belgrade-Faculty of Agriculture, Nemanjina 6, 11080 Belgrade, Serbia; Jelena Jović and Slobodan Krnjajić, Department of Plant Pests, Institute for Plant Protection and Environment, Banatska 33, 11080 Belgrade, Serbia; and Ana Vučurović and Branka Krstić, Institute of Plant Protection, Department of Phytopathology, University of Belgrade-Faculty of Agriculture, Serbia

\begin{abstract}
Bulajić, A., Djekić, I., Jović, J., Krnjajić, S., Vučurović, A., and Krstić, B. 2010. Phytophthora ramorum occurrence in ornamentals in Serbia. Plant Dis. 94:703-708.

In a survey to determine the presence of Phytophthora ramorum in Serbia, ornamentals from garden centers, nurseries, and private and public gardens, as well as imported plant material, were inspected. In total, 577 plant, soil, and potting media samples were tested using various detection methods: lateral flow diagnostic test, enzyme-linked immunosorbent assay, conventional polymerase chain reaction, and isolation, followed by identification based on growth characteristics in culture and morphological features. P. ramorum was not detected in any of the 162 soil or potting media tested by the baiting method. P. ramorum was detected in 12 Rhododendron samples from one private garden in Zemun (City of Belgrade District) exhibiting symptoms of leaf necrosis and blight and petiole necrosis, and in three samples of Pieris spp. from one garden center exhibiting symptoms of leaf necrosis. Eight Phytophthora isolates were obtained from the positive Rhododendron plants and three isolates from Pieris plants, and all were identified as $P$. ramorum on the basis of their uniform morphological and growth characteristics. $P$. ramorum conformation was also made by sequencing of the internal transcribed spacer regions for a single isolate taken from one infected rhododendron and one pieris plant. Serbian isolates were determined as A1 mating type, due to formation of a few typical sexual structures when crossed with the A2 mating type of $P$. cinnamomi and P. cryptogea. Pathogenicity test on nonwounded detached leaves of 19 popular ornamentals, as well as the most frequently imported ones, revealed that 10 host species were susceptible, including Robinia pseudoacacia, which is widely distributed in Serbia. During this study, Cotoneaster horizontalis and C. dammeri were determined to be new experimental hosts of $P$. ramorum. This article provides evidence of $P$. ramorum introduction into Serbia. Although P. ramorum has not been detected in Serbian production nurseries, its presence outdoors might cause severe damages on susceptible common urban plants in public green and natural ecosystems.
\end{abstract}

Phytophthora ramorum Werres, De Cock \& Man in 't Veld, an oomycete in the Stramenopila kingdom, is an exotic pathogen causing two kinds of diseases with different types of symptoms: sudden oak death (SOD) in North America, with bleeding lesions and stem canker on oak trees; and ramorum blight, with twig dieback or foliar lesions on trees and woody ornamentals in forests, nurseries, and gardens in both Europe and North America $(9,16,21)$. Although these diseases were first noticed in the $1990 \mathrm{~s}, P$. ramorum was not considered to be very harmful in Europe (17). However, the status of $P$. ramorum was changed in Europe when it was identified as the causal agent of SOD in California, causing serious problems on oak trees (34). As a result, the European

Corresponding author: B. Krstić

E-mail: branka.krstic@agrif.bg.ac.rs

Accepted for publication 8 February 2010.

doi:10.1094/PDIS-94-6-0703

(C) 2010 The American Phytopathological Society
Union (EU) enforced phytosanitary emergency measures to prevent the spread of European as well as the introduction of non-European $P$. ramorum isolates in the EU (2). Until now, $P$. ramorum has been found in 21 countries in Europe (35), and seven U.S. states were found to have nurseries with plants that tested positive for $P$. ramorum (28) whereas, in California, Oregon, and Washington, it has been established in nature (4).

$P$. ramorum has a remarkably wide host range that currently includes over 100 plant species, both in nature and in ornamental nurseries (16). P. ramorum is considered to be an aboveground plant pathogen $(18,45)$ but also has a soil phase $(37)$. This pathogen is able to survive in soil and is infective for the roots of rhododendron (32). In infected plant tissue, $P$. ramorum produces chlamydospores for long-term survival (8) which, in a favorable environment, develop to form numerous sporangia (37). Germination or release of zoospores depends upon conditions, although it has been shown that zoospores are more infective than sporangia (45). There are three currently known clonal lineages of $P$. ramorum: NA1 (isolates of A2 mating type from forests and nurseries in North America), NA2 (A2; nurseries in North America), and EU1 (predominantly A1, rarely A2; nurseries, gardens, and woodlands in Europe and North America) (14,22,23). Until now, the sexual cycle of $P$. ramorum has not been documented in nature, and formation of oospores could be induced only by pairing with the opposite mating type of some heterothallic Phytophthora spp. under controlled conditions $(6,43)$.

Continual detection of $P$. ramorum in ornamental nursery stocks in North America and Europe raised concern about potential spread through plant material trade. All around the world, quarantine efforts are undertaken to control the spread of this harmful organism. Surveys were conducted in many countries in order to establish the presence and distribution of $P$. ramorum, including Canada (1), North Carolina (21,41), Oregon (31), Minnesota (36), Sweden (25), the Netherlands (17), and Spain (30). Investigations like these are continuously conducted due to major concern about long-term negative impact on the environment and economy (5).

At the beginning of 2006, an intensive survey was initiated in Serbia, according to the European Commission Decision 2002/757/EC (2), and the experiences of other European countries that showed that $P$. ramorum posed a high risk and potentially destructive impact on forests and natural ecosystems. A preliminary report on the first finding of $P$. ramorum in Serbia was published (7), encouraging further investigation of the presence of $P$. ramorum in Serbia. The primary objective of this study was to gain insight into the occurrence and distribution of $P$. ramorum in Serbia by sampling and testing (i) imported ornamental plants; (ii) particular ornamental species as potential host plants in garden centers, nurseries, and open gardens; and (iii) soil and potting media in which inspected plants were grown or delivered. In addition, preliminary susceptibility assessment of several frequently distributed and mostly imported ornamentals was made to evaluate their potential as $P$. ramorum hosts in Serbia.

\section{MATERIALS AND METHODS}

Sample collection. During 2006 to 2008, an extensive survey was conducted 
in order to detect the presence of $P$. ramorum in Serbia. The survey included ornamentals from garden centers and other retail facilities and, to a lesser degree, production nurseries and private and public gardens, as well as ornamentals imported into Serbia. In total, over the course of the surveys, 8,981 plants from 13 genera that are known to be $P$. ramorum host plants (Acer, Camellia, Rhododendron, Pyracantha, Rosa, Viburnum, Vaccinium, Cotoneaster, Lonicera, Taxus, Syringa, Pieris, and Leucothoe) were visually inspected and 577 samples were collected, including 415 samples of plant tissue and 162 samples of soil and potting media (Table 1).

Samples were collected from plants that exhibited symptoms resembling those of foliar infection by $P$. ramorum, such as necrotic leaf lesions with diffuse margins and twig and branch necrosis $(31,44)$. Samples of leaves, twigs, and branches were also collected from a number of plants with atypical disease symptoms, as well as from some asymptomatic plants in which the sampling and detection focused on leaf tips and petioles. Sampled plant tissues were sealed in plastic bags with a piece of damp paper after collection and processed within $72 \mathrm{~h}$ after arrival to the laboratory.

Whenever possible, potting media or soil surrounding sampled plants were collected and tested for the presence of $P$. ramorum using the baiting technique (39) with leaves of Rhododendron variegatum and $R$. morgenrot, previously shown to be susceptible (7). Each sample consisted of approximately $200 \mathrm{~g}$ of potting media or soil from a depth of up to $10 \mathrm{~cm}$. These samples were tested by flooding with distilled water and baiting with healthy rhododendron leaves. After 5 to 7 days, all baiting leaves showing symptoms were removed, blotted on paper towels, surface sterilized, and further analyzed using culturing and molecular detection, as described for plant tissue material.

Lateral flow diagnostic test. A lateral flow diagnostic (LFD) test was performed using the Alert LF Phytophthora spp. kit (Neogen Europe Ltd., United Kingdom), following the manufacturer's instructions. Pieces of plant tissue were placed into bags with extraction buffer and homogenized. Two drops of suspension were put onto each LFD device using a pipette, allowing them to run along the membrane. Results were recorded up to 3 min after the appearance of the blue control line. The appearance of the second blue test line indicated that the sample was positive.

Enzyme-linked immunosorbent assay. The double-antibody sandwich enzymelinked immunosorbent assay (DASELISA) was performed using the Phytophthora PathoScreen Kit (Agdia Inc., Indiana), according to the manufacturer's instructions. An ELISA detection kit was used for Phytophthora spp. detection directly on plant samples, as well as on fragments of fungal colonies on agar during the isolation and culturing of suspected isolates. Leaf tissue samples of $30 \mathrm{mg}$ or agar colony fragments with total area of 1 $\mathrm{cm}^{2}$ were homogenized with pestle and mortar in $300 \mu$ of the kit's GEB2 buffer. The homogenized mixture was centrifuged for $1 \mathrm{~min}$ at $14,000 \times g$ and $100 \mu \mathrm{l}$ of the resulting supernatant was used for the DAS-ELISA. Lyophilized positive and negative controls provided with the kit were rehydrated in $2 \mathrm{ml}$ of GEB2 buffer as recommended. Two replicates were used for each sample and commercial positive and negative controls were included in each ELISA. Absorbance at $405 \mathrm{~nm}$ was measured $1 \mathrm{~h}$ after addition of the kits PNP substrate using an ELISA microplate reader (DASsrl, Italy). Samples with absorbency values two or more times higher than the negative control were considered positive for the presence of Phytophthora spp. The average value of the negative control was 0.054 .

Culturing. Plant samples were washed in tap water and surface sterilized with $70 \%$ ethanol; then, small pieces of material (approximately $1 \mathrm{~cm}^{2}$ each) from the leading edge of symptomatic tissue were placed on Phytophthora semiselective media $\mathrm{P}_{5} \mathrm{ARP}[\mathrm{H}]$ and the fungal colonies

Table 1. Number of samples inspected and tested for the presence of Phytophthora ramorum in Serbia during 2006 to 2008

\begin{tabular}{|c|c|c|c|c|c|c|c|c|}
\hline \multirow[b]{2}{*}{ Host plants } & \multirow[b]{2}{*}{ Year } & \multirow[b]{2}{*}{ No. of plants ${ }^{c}$} & \multicolumn{2}{|c|}{ No. of tested samples ${ }^{\mathrm{a}}$} & \multicolumn{4}{|c|}{ P. ramorum presence ${ }^{b}$} \\
\hline & & & Tissue & Potting & LFD & ELISA & Culture & PCR \\
\hline \multicolumn{9}{|l|}{ Imported ornamentals } \\
\hline Acer sp. & 2006 & 120 & 2 & 2 & 0 & 0 & 0 & 0 \\
\hline Camellia japonica & 2006 & 130 & 3 & 1 & 0 & 0 & 0 & 0 \\
\hline \multirow[t]{3}{*}{ Rhododendron sp. } & 2006 & 1,680 & 92 & 28 & $7^{\mathrm{d}}$ & $8^{\mathrm{d}}$ & 0 & 0 \\
\hline & 2007 & 1,340 & 45 & 18 & $4^{\mathrm{d}}$ & $4^{\mathrm{d}}$ & 0 & 0 \\
\hline & 2008 & 160 & 3 & 3 & $1^{\mathrm{d}}$ & $1^{\mathrm{d}}$ & 0 & \\
\hline \multirow[t]{2}{*}{ Pyracantha sp. } & 2006 & 240 & 3 & 1 & 0 & 0 & 0 & 0 \\
\hline & 2007 & 198 & 7 & - & 0 & 0 & 0 & 0 \\
\hline Rosa sp. & 2006 & 3,460 & 93 & 12 & 0 & 0 & 0 & 0 \\
\hline Viburnum sp. & 2008 & 50 & 1 & 1 & 0 & 0 & 0 & 0 \\
\hline \multirow{3}{*}{ Vaccinium sp. } & 2006 & 230 & 21 & 11 & 0 & 0 & 0 & 0 \\
\hline & 2007 & 190 & 34 & 12 & 0 & 0 & 0 & 0 \\
\hline & 2008 & 220 & 12 & - & 0 & 0 & 0 & 0 \\
\hline \multicolumn{9}{|l|}{ Garden centers } \\
\hline Camellia japonica & 2008 & 65 & 12 & 12 & 0 & 0 & 0 & 0 \\
\hline Rhododendron sp. & 2008 & 140 & 21 & 21 & $3^{\mathrm{d}}$ & $3^{\mathrm{d}}$ & 0 & 0 \\
\hline Pyracantha sp. & 2008 & 40 & 12 & 12 & 0 & 0 & 0 & 0 \\
\hline Viburnum sp. & 2008 & 65 & 6 & 6 & 0 & 0 & 0 & 0 \\
\hline Pieris sp. & 2008 & 64 & 7 & - & 3 & 3 & 3 & 3 \\
\hline Leucothoe sp. & 2008 & 42 & 4 & - & 0 & 0 & 0 & 0 \\
\hline \multicolumn{9}{|l|}{ Nurseries } \\
\hline Cotoneaster sp. & 2008 & 240 & 3 & 3 & 0 & 0 & 0 & 0 \\
\hline Lonicera sp. & 2008 & 125 & 2 & 6 & 0 & 0 & 0 & 0 \\
\hline Pyracantha sp. & 2008 & 80 & 7 & 6 & 0 & 0 & 0 & 0 \\
\hline Taxus sp. & 2008 & 80 & 3 & 5 & 0 & 0 & 0 & 0 \\
\hline \multicolumn{9}{|c|}{ Public and private gardens } \\
\hline Rhododendron sp. & 2008 & 15 & 15 & - & 12 & 12 & 8 & 12 \\
\hline Viburnum sp. & 2008 & 3 & 3 & 1 & 0 & 0 & 0 & 0 \\
\hline Syringa sp. & 2008 & 4 & 4 & 1 & 0 & 0 & 0 & 0 \\
\hline
\end{tabular}


obtained were later transferred to CPA (44). $\mathrm{P}_{5} \mathrm{ARP}[\mathrm{H}]$ was prepared as conventional corn meal agar amended with antibiotics pimaricin, ampicillin, rifampicin, and pentachloronitrobenzene. CPA was prepared from $50 \mathrm{~g}$ of carrot pieces and 20 $\mathrm{g}$ of agar per $1,000 \mathrm{ml}$ of distilled water. The initial isolations were performed on $\mathrm{P}_{5} \mathrm{ARP}[\mathrm{H}]$; the plates were kept at $20^{\circ} \mathrm{C}$ in the dark and inspected for Phytophthora spp. types of colonies after 7 days. All Phytophthora-like colonies were further cultured on CPA and, after that, identified by ELISA. All ELISA-positive isolates were identified on the basis of their growth characteristics in culture and morphological features (44).

Molecular detection. Molecular detection and identification of $P$. ramorum isolates were performed with nested polymerase chain reaction (PCR), using internal transcribed spacer (ITS) primers Phyto1 (5'-CAT GGC GAG CGC TTG A$\left.3^{\prime}\right)$ and Phyto4 (5'-GAA GCC GCC AAC ACA AG-3') in the first round and Phyto2 (5'-AAA GCC AAG CCC TGC AC- $3^{\prime}$ ) and Phyto3 (5'-GGT GGA TGG GGA CGT G$3^{\prime}$ ) in the second round, as described by Hayden et al. (20).

Bulk DNA was isolated directly from $100 \mathrm{mg}$ of sampled plant tissue of leaves, twigs, or branches, as well as from cultured mycelia using the Qiagen DNeasy Plant Mini Kit (Qiagen, Hilden, Germany), according to the manufacturer's instructions. DNA was extracted in $100 \mu \mathrm{l}$ of elution buffer and further used as a target in PCR reaction. Each $25 \mu \mathrm{l}$ of reaction mixture contained $12.5 \mu \mathrm{l}$ of $2 \times$ PCR master mix containing $2 \mathrm{mM} \mathrm{MgCl}$ (Fermentas Life Sciences GmbH, Lithuania), 6.25 $\mu \mathrm{l}$ of template DNA, and $1 \mu \mathrm{l}$ of $10 \mu \mathrm{M}$ each primer. The remainder of the master mix reaction was made up of sterile molecular-grade water. PCR cycling conditions were the following: an initial denaturation at $94^{\circ} \mathrm{C}$ for $85 \mathrm{~s}$; followed by 35 cycles of $93^{\circ} \mathrm{C}$ for $35 \mathrm{~s}, 62^{\circ} \mathrm{C}$ for $55 \mathrm{~s}$, and $72^{\circ} \mathrm{C}$ for $50 \mathrm{~s}$ each; and a final extension at $72^{\circ} \mathrm{C}$ for $10 \mathrm{~min}$. Products from the first amplification were diluted $1 / 500$ in molecular-grade water, then subjected to the second amplification using primer set Phyto2/Phyto3. The protocol for the second round used exactly the same reaction reagents and conditions as for the Phyto1/Phyto4 amplification. Amplified fragments were separated by electrophoresis on a $1 \%$ agarose gel, stained with ethidium bromide in Tris-borate-EDTA buffer, and visualized under UV light.

Sequencing. For DNA isolation, a single hyphal-tip culture of isolate Pr92-08, originating from Rhododendron spp., and isolate Pr6-08, originating from Pieris spp., was grown in pea broth for 7 days at room temperature $\left(21\right.$ to $\left.23^{\circ} \mathrm{C}\right)(21)$. Pea broth was prepared by autoclaving $120 \mathrm{~g}$ of frozen peas in $500 \mathrm{ml}$ of deionized water. After filtration through several layers of cheesecloth, the filtrate was brought up to $1,000 \mathrm{ml}$ with deionized water and autoclaved for $25 \mathrm{~min}$. Mycelia of the isolates were filtered and collected in $1.5-\mathrm{ml} \mathrm{mi-}$ crotubes, and the DNA was extracted by the Qiagen DNeasy Plant Mini Kit (Qiagen) according to the manufacturer's instructions.

Amplification products of predicted size, obtained using Phyto1/Phyto4 primers (20) and derived from the isolates Pr92-08 and Pr6-08, were sequenced directly after the purification with the QUIAqick PCR Purification Kit (Qiagen). Sequencing was performed on automated equipment (BMR Genomics, Padova, Italy) using both primers. The nucleotide sequences of the amplification products were deposited in the National Center of Biotechnology Information (NCBI) GenBank database and compared online with those of previously reported $P$. ramorum isolates using BLAST (http://www.ncbi. nlm.nih.gov/BLAST/).

Determination of mating type. Single hyphal-tip cultures of isolates Pr92-08 and Pr6-08, originating from rhododendron and pieris plants, respectively, were used for determination of mating types by pairing with $\mathrm{A} 1$ and $\mathrm{A} 2$ tester isolates of five different Phytophthora spp.: P. cambivora (BBA 21/95-KII, A1 and BBA 20/95-2b III, A2), P. cinnamomi (BBA 69094, A1 and BBA 62660, A2), P. cryptogea (BBA 65909, A1 and BBA63651, A2), $P$. drechsleri (BBA 65172, A1 and BBA 62679, A2), and P. ramorum (BBA 9/95, A1 and BBA 26/02, A2) (44). The isolates were tested by mycelial mixing on thin carrot agar (CA; 6). CA was prepared by liquidizing $200 \mathrm{~g}$ of carrot in $500 \mathrm{ml}$ of tap water, filtering through cheesecloth, and bringing the filtrate up to $1,000 \mathrm{ml}$ with tap water. After autoclaving, CA was poured into petri dishes to form thin layers (10 $\mathrm{ml} /$ plate). Both isolates to be tested and all tester isolates were subcultured on thin CA and incubated for 3 days at $20^{\circ} \mathrm{C}$ in the dark. After 3 days, all the isolates were subcultured again under the same conditions. Each isolate was paired with a tester isolate of known mating type. A small colony piece of each isolate to be tested was grown together in mycelial mix with each tester isolate of known mating type of each Phytophthora sp. and incubated for 4 to 7 days at $20^{\circ} \mathrm{C}$ in the dark. After incubation, plates were searched for gametangia by scanning the area under the mixed pieces of mycelia using a compound microscope. The formation of gametangia proved that the tested isolate was of the opposite mating type to the tester isolate.

Pathogenicity test. Pathogenicity of isolates Pr92-08, originating from rhododendron, and Pr6-08, originating from pieris, was tested on nonwounded detached leaves from 19 plant species that are widely distributed ornamentals in Serbia or frequently imported. The following 15 healthy host species were purchased from one garden center and maintained under greenhouse conditions for 8 months before inoculation: a Pyrachantha sp., Cotoneaster dammeri, $C$. horizontalis, Prunus cerasus, $P$. laurocerasus, $R$. simsii 'Helmut Vogel', R. simsii 'Tamira', R. simsii 'Vogel Luntera', $R$. ponticum 'Variegatum', $R$. yakushimanum 'Morgenrot', $R$. 'Cosmopolitan', Osmanthus heterophyllus 'Goshiki', Viburnum plicatum 'Mariesii', $V$. opulus 'Roseum', and Vaccinium vitisidea. Healthy leaves of four common urban ornamentals (Robinia pseudoacacia, Syringa vulgaris, Forsythia $\times$ intermedia, and a Magnolia sp.) were also freshly collected on the day scheduled for the inoculations. For inoculations, zoospore suspensions of the two isolates were prepared according to Denman et al. (11). The isolates were cultured on CPA and incubated in the dark at $20^{\circ} \mathrm{C}$ for 14 days. Cultures were flooded with $5 \mathrm{ml}$ of sterile water and sporangia were dislodged by rubbing the culture surfaces with a sterile, bent glass rod. The liquid was poured into a sterile beaker which was placed at $7^{\circ} \mathrm{C}$ for $1 \mathrm{~h}$ and then at $20^{\circ} \mathrm{C}$ for $75 \mathrm{~min}$ to induce zoospore release. The zoospore suspension concentrations were measured and adjusted to 1 to $4 \times 10^{5}$ zoospores $/ \mathrm{ml}$ by a hemacytometer. Selected plant leaves were washed in tap water, surface sterilized by wiping with cotton wool, moistened with $70 \%$ ethanol, and air dried. Leaves, with the adaxial sides down, were individually placed into petri dishes containing paper towels moistened with sterile water to maintain moisture during the entire experiment. The abaxial side of each leaf was inoculated by placing a $50-\mu l$ drop of prepared zoospore suspension. From each plant species, 10 fully developed healthy leaves were inoculated with zoospore suspension of each $P$. ramorum isolate, and 10 leaves were inoculated with sterile water and used as a negative control. The experiment was repeated twice. Symptom development was inspected daily for 15 days after the inoculation. The petri dishes containing test samples were incubated at $20^{\circ} \mathrm{C}$ in the dark.

\section{RESULTS}

During the course of the surveys, from 2006 to 2008, 577 samples from a total of 8,981 visually inspected plants were collected and tested for $P$. ramorum presence using several detection methods: LFD, ELISA, PCR, and isolation, followed by identification on the basis of growth characteristics in culture and morphological features. The presence of $P$. ramorum was not detected using any of the employed methods on the 5,860 visually inspected imported plants and 269 plant, soil, and potting media samples tested in 2006. Also, it was not detected in 1,728 inspected plants and 116 samples of different origin, collected and tested in 2007. Dur- 
ing 2008, 192 samples were tested out of 1,393 visually inspected imported plants and plants from garden centers, nurseries, and private and public gardens. $P$. ramorum was detected in 12 samples of rhododendron 'Baden-Baden' from one private garden in Zemun and in 3 samples of a Pieris sp. from one garden center (both from City of Belgrade District; Table 1). P. ramorum-positive Rhododendron plants exhibited symptoms of leaf necrosis and blight and petiole necrosis. Diseased tissue showed dark brown to black discoloration with dieback of shoot tips and brown spots with necrotic areas on the leaves. P. ramorum-positive Pieris plants exhibited symptoms of leaf necrosis, mainly starting from leaf tips. The presence of the pathogen was successfully detected using LFD, ELISA, culturing, and nested PCR as described.

The 162 samples of soil and potting media were tested by baiting and, of these, 23 produced bait leaves which showed necrosis. Of these, 15 were LFD positive; the same 15 samples plus 1 other were ELISA positive for the presence of $P$. ramorum but subsequent culturing and nested PCR, as species-specific tests, revealed no $P$. ramorum presence. From symptomatic rhododendron baiting leaves, 11 isolates were obtained, all exhibiting Phytophthora spp. morphological features. However, all of them formed typical oospore-like structures and, knowing that these isolates were nested PCR negative for $P$. ramorum and that it is a heterothallic and self-sterile species, these isolates were not further characterized.

Molecular detection. $P$. ramorum was successfully detected using nested PCR protocol in both the samples of symptomatic rhododendron plants from the private garden and pieris plants from the garden center. DNA extraction and PCR detection were successful in leaves, twigs, and branches of infected rhododendron, and in leaves of infected pieris plants.

Primer pair Phyto1/Phyto4, used in the first round of nested PCR, yielded one clear band of predicted size of $687 \mathrm{bp}$, and the second round of nested PCR, with primer pair Phyto2/Phyto3, resulted in one visible band of $291 \mathrm{bp}$ in all 12 rhododendron and 3 pieris plants, which were serologically and morphologically positive for P. ramorum.

Identification based on morphology. Eight isolates of Phytophthora spp. were obtained from LFD-, ELISA-, and PCRpositive rhododendron and three isolates were obtained from pieris plants. All of the isolates were identified as $P$. ramorum on the basis of their uniform morphological and growth characteristics on CPA.

The isolates were slow growing on CPA, with average daily growth of 2.7 to 3.1 $\mathrm{mm}$. The isolates formed whitish colonies with sparse aerial mycelia and pale, concentric rings. After 4 to 7 days, all $P$. ramorum isolates produced numerous semipapillate sporangia on CPA, arranged either singly or, more frequently, in clusters sympodially positioned on long sporangiophores. Sporangia dimensions were 35 to 80 (54) by 17 to 32 (26) $\mu \mathrm{m}$. Besides sporangia, all the isolates formed numerous large, thin-walled chlamydospores, positioned intercalary or terminally. Chlamydospores were hyaline to slightly pigmented, with dimensions ranging from 35 to $62(48) \mu \mathrm{m}$ in diameter.

Identification based on sequencing. Sequences of the ITS region of representative isolates Pr92-08 (GenBank accession no. EU915480), originating from rhododendron, and Pr06-08 (GQ258666), originating from pieris, proved to be identical at the nucleotide level of 99 to $100 \%$ with $P$. ramorum isolates in the NCBI GenBank database.

Mating type determination. Both Pr92-08 and Pr6-08 were determined to be A1 mating type, due to formation of a few typical sexual structures when crossed with A2 mating type of $P$. cinnamomi and $P$. cryptogea. The sexual structures were not formed when these isolates were crossed with both mating types of $P$. cambivora, $P$. drechsleri, and $P$. ramorum tester isolates. Oogonia, amphigynous antheridia, and oospores were difficult to find because they were formed in small numbers.

Experimental host range. Out of 19 tested plant species, frequently imported or widely distributed in Serbia, 10 were susceptible to infection with both the representative $P$. ramorum isolates used in this study. Inoculated leaves exhibited necrotic lesions of different sizes, which coalesced, in time covering the entire leaflet. During the experiment, the differences in pathogenicity between two $P$. ramorum isolates originating from Serbia were not observed. Using both $P$. ramorum isolates, first symptoms of necrotic spots were visible as early as after 3 days on the following four plant species: Rhododendron ponticum 'Variegatum' (20 infected/20 inoculated leaves), $R$. yakushimanum 'Morgenrot' (20/20), Viburnum plicatum 'Mariesii' (20/20), and Robinia pseudoacacia (20/20). The following six species developed first visible symptoms after 7 days: C. horizontalis (20/20), C. dammeri (18/20), Vaccinium vitis-idea (18/20), V. opulus 'Roseum' (15/20), Prunus laurocerasus (14/20), and Rhododendron 'Cosmopolitan' (13/20), while the remaining nine plant species could not be infected: Pyrachantha sp., $P$. cerasus, $R$. simsii 'Helmut Vogel', R. simsii 'Tamira', $R$. simsii 'Vogel Luntera', O. heterophyllus 'Goshiki', S. vulgaris, Forsythia $\times$ intermedia, and a Magnolia sp.

Reisolation of the fungus confirmed the identity of the pathogen morphologically, thus fulfilling Koch's postulates. The pathogen was also successfully detected by
PCR in all symptomatic leaves. $P$. ramorum was not isolated nor was it detected by nested-PCR protocol from any asymptomatic inoculated leaves. The leaves inoculated with sterile water showed no reactions.

\section{DISCUSSION}

Production of ornamentals has been growing rapidly in Serbia, because of the increasing popularity and high trade value of ornamental plant species. Their import into Serbia, especially potted plants, is also high, showing a trend that almost doubles its value every year. The import of all categories of ornamentals exceeded the value of US\$12 million in 2004, including more than US\$4.5 million spent only on potted plants. International movement of plants is seen by many as a major pathway for the introduction of many pathogens, including exotic ones, such as $P$. ramorum $(24,30)$.

Among plant species favored for horticultural purposes, species of Rhododendron, Viburnum, Pieris, Syringa, Camellia, and Taxus would most likely become infected by $P$. ramorum, and some of them have been involved in moving the pathogen through the international ornamental trade and nursery shipments $(16,29)$. During the last few years in Serbia, the popularity of rhododendrons has been increased substantially but, because they are not produced in Serbian nurseries, the number of imported plants has been increasing constantly. The production of other $P$. ramorum-susceptible host plants, such as Cotoneaster, Magnolia, Pyracantha, Lonicera, and Taxus spp., is registered in Serbia but is still of significantly smaller scale than their import. In consideration of these facts, inspection and sampling during the survey included only a limited number of nurseries, instead focusing closer attention on imported ornamentals and plants in garden centers. First isolated from rhododendron and viburnums in nurseries in the Netherlands and Germany (44), $P$. ramorum can now be found not only in nurseries and garden centers but also in private gardens and estates open to the public, as well as in natural ecosystems $(3,10)$. Investigations performed by Moralejo and Descals (29) indicated the importance of imported rhododendrons as a common pathway of $P$. ramorum to enter into Spain, and reported that the inoculum can spread from garden centers to natural vegetation either through dispersal or by transplantation of infected plants in private gardens. This is why the survey included a certain number of public and private gardens.

During a 3-year survey for the presence of $P$. ramorum in Serbia, the pathogen was not detected in visually inspected imported plants, nor was it in the samples collected from Serbian nurseries. The survey included both symptomatic and, to a limited extent, randomly selected symptomless 
leaves of susceptible plants. Because of reported $P$. ramorum sporulation in symptomless plants $(12,31)$, a number of asymptomatic leaves of susceptible plants was tested in which all were negative for $P$. ramorum using all the detection methods described in this article. Baiting method for Phytophthora sp. detection, successfully used in similar investigations $(8,39)$, confirmed the presence of several isolates of homothallic Phytophthora spp.; however, $P$. ramorum was not detected in any soil or potting media sample.

In all 8,981 plants inspected during our survey and 577 tested samples, $P$. ramorum was detected in 12 rhododendron plants from one private garden in Zemun and 3 symptomatic pieris plants from a garden center in Belgrade district. This represented a detection rate of 0.17 and $2.6 \%$, calculated in relation to the number of inspected plants and tested samples, respectively. In similar surveys, Gruyter and Steeghs (17) found sites with rhododendron to have approximately $2 \%$ levels of $P$. ramorum infection, while Warfield et al. (41) found levels of $2.4 \%$ in pieris nurseries and $10 \%$ when testing rhododendron cultivars.

Using the simple detached-leaf assay, susceptibility to $P$. ramorum of the nine most frequently imported ornamentals in Serbia was determined, indicating that they may be a potential source of inoculum for further spread and possible tree epidemics. The intensity and short time of symptom development implied high susceptibility of four inoculated hosts ( $R$. ponticum 'Variegatum', $R$. yakushimanum 'Morgenro', Viburnum plicatum 'Mariesii', and Robinia pseudoacacia), indicating that those ornamentals should be selected target hosts in thorough border inspections. Among ornamentals susceptible to $P$. ramorum, six species belong to naturally infected hosts and one is categorized as a potential host of $P$. ramorum (35). $C$. horizontalis and $C$. dammeri have not been listed as $P$. ramorum hosts so far but the results of this investigation indicate that they should be treated as possible hosts because they were severely affected by artificial inoculation.

$R$. pseudoacacia identified as highly susceptible to $P$. ramorum through inoculation studies conducted on experimental host range. This result provide a basis for a further survey to select that landscape tree, commonly found in Seriba, as a target host. Although it was proven that R. pseudoacacia is highly susceptible to the pathogen by artificial inoculation (40) and another species, $R$. hispida, was found to be very susceptible in the similar inoculation experiment (28), this very popular landscape tree has not been included in the current list of $P$. ramorum naturally infected hosts $(4,35)$.

Interestingly, $S$. vulgaris, a Magnolia sp., a Pyrachantha sp., and O. heterophyllus did not show any reaction after inocula- tion, although they are proven to be natural hosts of $P$. ramorum $(4,35)$. Because of considerable susceptibility variation among different plant species within the same genus or even different cultivars within a single species $(16,33,38)$, further assessment of cultivar susceptibility is needed, both in terms of leaf lesion area development and pathogen sporulation capacity.

By using the current LFD and ELISA methods, large-scale testing can be performed quickly to diagnose for the presence of Phytophthora spp. (27). These serological techniques were used in this investigation as prescreening tests which detected the presence of Phytophthora spp., later identified as $P$. ramorum or homothallic Phytophthora spp.

The detection methods in this investigation showed slightly different detection efficiencies. PCR detection of $P$. ramorum was successful in either leaves, twigs, or branches for each of the samples which gave LFD and ELISA positives. However, isolation was possible from each pieris plant and only 8 of the 12 rhododendrons. Isolation failure was consistent with signs of sample decomposition and the presence of saprophytic fast-growing fungi which overgrew the targeted $P$. ramorum. Isolation of $P$. ramorum is not always successful because recovery rates depend on sample suitability, freshness of the material, fungal viability, host type, and time of the year $(20,26,27,44)$.

$P$. ramorum-positive Pieris plants, collected from the garden center, were imported and offered for sale. Most probably, those plants were symptomless during the border inspection, which implies the necessity for more frequent sampling and testing of $P$. ramorum-susceptible host plants, regardless of the symptom occurrence. The main concern in the majority of countries is how to avoid the high risk of $P$. ramorum spread to its alternative potential hosts, once it is introduced into garden centers or private gardens (29). According to $P$. ramorum's status in Serbia as an A1 quarantine organism and according to EU legislation, phytosanitary measures were applied and the rest of the plants were destroyed at the sites of the pathogen outbreak.

The presence of both mating types in U.S. $(15,19)$ and Belgian nurseries $(42)$, as well as the detection of a $P$. ramorum isolate suspected to be a recombinant (13), suggests a possibility for sexual recombination $(16,43)$. Taking into account the importance of mating type determination of obtained isolates, especially in a new geographic region of occurrence, both representative isolates found in Serbia were characterized and determined to be A1 mating type, belonging to the European population.

Although $P$. ramorum has not been detected in Serbian nurseries, its detection on
Rhododendron plants outdoors might pose a serious threat to public green and natural ecosystems. Climate similarity of 70 to $80 \%$ between west and southwest Serbia and California (35), as well as the presence of susceptible host plants in the urban and natural landscape of Serbia, make the threat of $P$. ramorum even more serious.

\section{ACKNOWLEDGMENTS}

We thank S. Werres, Julius Kuehn Institute (JKI), Federal Research Centre for Cultivated Plants, Institute for Plant Protection in Horticulture and Forests (GF) Messeweg 11/12, D-38104 Braunschweig for providing mating type tester isolates. This investigation was partly supported by grant 321-01-753/2004-11/2 financed by Ministry of Agriculture, Forestry, and Water Management of Serbia.

\section{LITERATURE CITED}

1. Allen, E., Callan, B., Cree, L., and Sela, S. 2003. The impact of Phytophthora ramorum on Canada. Sudden Oak Death Online Symposium. doi.10.1094/SOD-2003-EA.

2. Anonymous. 2002. Commission Decision (2002/757/EC) of 19 September 2002 on provisional emergency phytosanitary measures to prevent the introduction into and the spread within the Community of Phytophthora ramorum Werres, De Cock \& Man in 't Veld sp. nov. Off. J. Eur. Communities 2002-09-20, L. 252:37-39.

3. Anonymous. 2003. Situation of Phytophthora ramorum in EPPO countries. Rep. No. 2003/133. EPPO Reporting Service, Paris.

4. Anonymous. 2008. Plant Health: Phytophthora ramorum. www.aphis.usda.gov/plant_health

5. Brasier, C. M. 2008. The biosecurity threat to the UK and global evironment from international trade in plants. Plant Pathol. 57:792-808.

6. Brasier, C. M., and Kirk, S. A. 2004. Production of gametangia by Phytophthora ramorum in vitro. Mycol. Res. 108:823-827.

7. Bulajić, A., Jović, J., Krnjajić, S., Djekić, I., and Krstić, B. 2009. First report of Phytophthora ramorum on Rhododendron $\mathrm{sp}$. in Serbia. Plant Pathol. 58:804.

8. Dart, N. L., Chastagner, G. A., Rugarber, E. F. and Riley, K. L. 2007. Recovery frequency of Phytophthora ramorum and other Phytophthora spp. in the soil profile of ornamental retail nurseries. Plant Dis. 91:1419-1422.

9. Davidson, J. M., Werres, S., Garbelotto, M., Hansen, E. M., and Rizzo, D. M. 2003. Sudden oak death and associated diseases caused by Phytophthora ramorum. Plant Health Progress. Online-publication. doi: 10.1094/PHP-20030707-01-DG.

10. Denman, S., Kirk, S. A., Brasier, C. M., Barton, V. C., Hughes, K. J. D., and Webber, J. F. 2005. Phytophthora ramorum on Quercus ilex in the United Kingdom. Plant Dis. 89:1241.

11. Denman, S., Kirk, S. A., Brasier, C. M., and Webber, J. F. 2005. In vitro leaf inoculation studies as an indication of tree foliage susceptibility to Phytophthora ramorum in the UK. Plant Pathol. 54:512-521.

12. Denman, S., Kirk, S. A., Moralejo, E., and Webber, J. F. 2009. Phytophthora ramorum and $P$. keronviae on naturaly infected asymptomatic foliage. Bull. OEPP/EPPO Bull. 39:105-110.

13. Garbelotto, M., Ivors, K. L., Hüberli, D. Bonants, P., and Wagner, A. 2006. Potential for sexual reproduction of Phytophthora ramorum in Washington state nurseries. Pages 129-130 in: Proc. Sudden Oak Death Second Symp.: The State of Our Knowledge. S. J. Frankel, P. J. Shea, and M. I. Haverty, eds. Monterey, CA.

14. Grünwald, N. J., Goss, E. M., Ivors, K., Garbelotto, M., Martin, F. N., Prospero, S., Hansen, 
E., Bonants, P. J. M., Hamelin, R. C., Chastagner, G., Werres, S., Rizzo, D. M., Abad, G., Beales, P., Bilodeau, G. J., Blomquist, C. L., Brasier, C. M., Briere, S. C., Chandelier, A., Davidson, J. M., Denman, S., Elliott, M., Frankel, S. J., Goheen, E. M., de Gruyter, H., Heungens, K., James, D., Kanaskie, A., McWiliams, M. G., Man in 't Veld, W., Moralejo, E., Osterbauer, N. K., Palm, M. E., Parke, J. L., Perez Sierra, A. M., Shamoun, S. F., Shishkoff, N., Tooley, P. W., Vettraino, A. M., Webber, J., and Widmer, T. L. 2009. Standardizing the nomenclature for clonal lineages of the sudden oak death pathogen, Phytophthora ramorum. Phytopathology 99:792-795.

15. Grünwald, N. J., Goss, E. M., Larsen, M. M., Press, C. M., McDonald, V. T., Blomquist, C., and Thomas, S. L. 2008. First report of the European lineage of Phytophthora ramorum in a California nursery. Plant Dis. 2:314.

16. Grünwald, N. J., Goss, E. M., and Press, C. M. 2008. Phytophthora ramorum: a pathogen with a remarkably wide host range causing oak death on oaks and ramorum blight on woody ornamentals. Mol. Plant Pathol. 9:729-740.

17. Gruyter de, J., and Streeghs, M. H. C. G. 2006. Managing Phytophthora ramorum in the Netherlands. Bull. OEPP/EPPO Bull. 36:399-401.

18. Hansen, E. M., Parke, J. L., and Sutton, W. 2005. Susceptibility of Oregon forest trees and shrubs to Phytophthora ramorum: a comparison of artificial inoculation and natural infections. Plant Dis. 89:63-70.

19. Hansen, E. M., Reeser, P. W., Sutton, W., Winton, L. M., and Osterbauer, N. K. 2003. First report of A1 mating type of Phytophthora ramorum in North America. Plant Dis. 87:1267.

20. Hayden, K. J., Rizzo, D., Tse, J., and Garbelotto, M. 2004. Detection and quantification of Phytophthora ramorum from California forests using real-time polymerase chain reaction assay. Phytopathology 94:1075-1083.

21. Hwang, J., and Benson, D. M. 2005. Identification, mefonoxam sensitivity, and compatibility type of Phytophthora spp. attacking floriculture crops in North Carolina. Plant Dis. 89:185-190.

22. Ivors, K. L., Garbelotto, M., Vries, I. D. E., Ruyter-Spira, C., Hekkert, B. T., Rosenzweig, N., and Bonants, P. J. M. 2006. Microsatelite markers identify three lineages of Phytophthora ramorum in US nurseries, yet single lineages in US forests and European nursery populations. Mol. Ecol. 15:1493-1505.

23. Ivors, K. L., Hayden, K. J., Bonants, P. J. M., Rizzo, D. M., and Garbelotto, M. 2004. AFLP and phylogenic analyses of North American and European populations of Phytophthora ramorum. Mycol. Res. 108:378-392.

24. Jones, D. R., and Baker, R. H. A. 2007. Introductions of non-native plant pathogens into Great Britain, 1970-2004. Plant Pathol. 56: 891-910

25. Jonsson, U., Jung, T., Sonesson, K., and Rosengren, U. 2005. Relationships between health of Quercus robur, occurrence of Phytophthora species and site conditions in southern Sweden. Plant Pathol. 54:502-511.

26. Kox, L. F. F., van Brouwershaven, I. R., van de Vossenberg, B. T. L. H., van den Beld, H. E., Bonants, P. J. M., and de Gruyter, J. 2007. Diagnostic values and utility of immunological, morphological, and molecular methods for in planta detection of Phytophthora ramorum. Phytopathology 97:1119-1129.

27. Lane, C. R., Hobden, E., Walker, L., Barton, V. C., Inman, A. J., Hughes, K. J. D., Swan, H., Colye, A., and Barker, I. 2007. Evaluation of a rapid diagnostic field test kit for identification of Phytophthora species, including P. ramorum and $P$. kernoviae at the point of inspection. Plant Pathol. 56:828-835.

28. Linderman, R. G., de Sả, P. B., and Davis, E. 2007. Comparative susceptibility of plants native to Appalachian range of the United States to inoculation with Phytophthora ramorum. Plant Health Progress. Online-publication. doi: 10.1094/PHP-2007-0971-01-RS

29. Moralejo, E., and Descals, E. 2003. Risk analysis of Phytophthora ramorum establishment in the Mediterranean area. Sudden Oak Death Online Symposium. doi: 10.1094/SOD2003-EM

30. Moralejo, E., Pérez-Sierra, A. M., Álvarez, L. A., Belbahri, L., Lefort, F., and Descals, E. 2009. Multiple alien Phytophthora taxa discovered on diseased ornamental plants in Spain. Plant Pathol. 58:100-110.

31. Osterbauer, N. K., Griesbach, J. A., and Hedberg, J. 2004. Surveying for and eradicating Phytophthora ramorum in agricultural commodities. Plant Health Progress. Onlinepublication. doi: 10.1094/PHP-2004-0309-02RS

32. Parke, J. L., and Lewis, C. 2007. Root and stem infection of Rhododendron from potting medium infested with Phytophthora ramorum. Plant Dis. 91:1265-1270.

33. Parke, J. L., Linderman, R. G., and Hansen, E. M. 2002. Assessing the susceptibility of Pacific Northwest nursery plants to Phytophthora ramorum using a detached leaf assay. Poster Abstr. Sudden Oak Death Science Symposium, Monterey, CA. http://danr.ucop.edu/ihrmp/sod symp/poster/poster53.html

34. Rizzo, D. M., Garbelotto, M., Davidson, J. M., Slaughter, G. W., and Koike, S. T. 2002. Phy- tophthora ramorum as the cause of extensive mortality of Quercus spp. and Lithocarpus densiflorus in California. Plant Dis. 86:205214.

35. Sansford, C. E., Inman, A. J., Baker, R., Brasier, C. M., Frankel, S., de Gruyter, J., Husson, C., Kehlenbeck, H., Kessel, G., Moralejo, E. Steeghs, M., Webber, J., and Werres, S. 2009 Report on the risk of entry, establishment, spread and socio-economic loss and environmental impact and the appropriate level of management for Phytophthora ramorum for the EU. Deliverable Report 28. EU Sixth Framework Project RAPRA. http://rapra.csl. gov.uk/

36. Schwingle, B. W., Smith, J. A., and Blanchette, R. A. 2007. Phytophthora species associated with diseased woody ornamentals in Minnesota nurseries. Plant Dis. 91:97-102.

37. Shishkoff, N. 2007. Persistence of Phy tophthora ramorum in soil mix and roots of nursery ornamentals. Plant Dis. 91:1245-1249.

38. Shishkoff, N. 2007. Susceptibility of some Lilac cultivars and other members of the Oleceae to Phytophthora ramorum. Plant Health Progress. Online-publication. doi: 10.1094/ PHP-2007-1101-02-RS

39. Themann, K., Werres, S., Diener, H. A., and Luttmann, R. 2002. Comparison of different methods to detect Phytophthora spp. in recycling water from nurseries. J. Plant Pathol. 84:41-50.

40. Tooley, P. W., and Browning, M. 2009. Susceptibility to Phytophthora ramorum and inoculum production potential of some common Eastern fores understory plant species. Plant Dis. 93:249-256.

41. Warfield, C. Y., Hwang, J., and Benson, D. M. 2008. Phytophthora blight and dieback in North Carolina nurseries during a 2003 survey. Plant Dis. 92:474-481

42. Werres, S., and De Merlier, D. 2003. First Detection of Phytophthora ramorum mating type A2 in Europe. Plant Dis. 87:1266.

43. Werres, S., and Kaminski, K. 2005. Characterization of European and North American Phytophthora ramorum isolates due to their morphology and mating behaviour in vitro with heterothallic Phytophthora species. Mycol. Res. 109:860-871.

44. Werres, S., Marwitz, R., Man in 't Veld, W. A De Cock, A. W. A. M., Bonants, P. J. M., De Weerdt, M., Themann, K., Ilieva, E., and Baayen, R. P. 2001. Phytophthora ramorum sp. nov., a new pathogen on Rhododendron and Viburnum. Mycol. Res. 105:1155-1165.

45. Widmer, T. L. 2009. Infective potential of sporangia and zoospores of Phytophthora ramorum. Plant Dis. 93:30-35. 